\title{
SOIL DEHYDROGENASE ACTIVITY: A COMPARISON BETWEEN THE TTC AND INT METHOD. A REVIEW
}

\author{
Susan Marlein Mambu ${ }^{1)}$ \\ 1) Jurusan Biologi FMIPA Universitas Sam Ratulangi, Manado \\ e-mail: susan.mambu@gmail.com
}

\begin{abstract}
Soil enzyme activities are very sensitive to both natural and anthropogenic disturbances and show a quick response to the induced change. Soil dehydrogenase enzyme are one of the main components of soil enzymatic activities participating in and assuring the correct sequence of all the biochemical routes in soil biogeochemical cycles. Dehydrogenase activity is measured by two methods using the TTC and INT substrate. Different biotic and abiotic factors such as incubation time and temperature, pre-incubation, soil aeration and moisture content have significant effect on dehydrogenase activity in soil. Dehydrogenase enzyme is often used as a measure of any disruption caused by pesticides, trace elements or management practices to the soil, as well as a direct measure of soil microbial activity. This review describes the role of intracellular enzymedehydrogenase in the soil environment, and the most common laboratory procedure used for measure dehydrogenase activity by two methods using the TCC and INT substrate.
\end{abstract}

Keywords: Dehydrogenase Activities, Flooded Soils, Soil Quality

\section{AKTIVITAS DEHIDROGENASE TANAH: KAJIAN PERBANDINGAN ANTARA TTC DAN METODE INT}

\begin{abstract}
ABSTRAK
Aktivitas enzim tanah sangat sensitif terhadap gangguan yang disebabkan oleh alam dan antropogenik dan menunjukkan respon yang cepat terhadap perubahan yang terjadi. Enzim tanah dehidrogenase adalah salah satu komponen utama dari aktivitas enzim tanah yang berpartisipasi dalam siklus biogeokimia tanah. Aktivitas dehidrogenase dapat diukur dengan menggunakan dua metode TTC dan INT substrat. Perbedaan faktor biotik dan abiotik seperti waktu inkubasi dan suhu, pre-inkubasi, aerasi tanah dan kadar air memiliki pengaruh yang signifikan pada aktivitas dehidrogenase dalam tanah. Enzim dehidrogenase sering digunakan sebagai ukuran dari gangguan yang disebabkan oleh pestisida, elemen atau manajemen pengelolaan tanah, serta dapat mengukur langsung aktivitas mikroba tanah. Ulasan ini menjelaskan peran enzim dehidrogenase intraseluler dalam lingkungan tanah, dan prosedur laboratorium yang paling umum digunakan untuk mengukur kegiatan dehidrogenase, yaitu dengan menggunakan metode TTC dan INT substrat.
\end{abstract}

Kata Kunci: Aktivitas Dehidrogenase Tanah, TTC, INT

\section{INTRODUCTION}

Interesting in evaluating the quality and health of our soil resources has been stimulated by increasing awareness that soil is a critically important component of the earth's biosphere, functioning not only in the production of food and fibre but also in the maintenance of local, regional, and global environmental quality. The thin layer of soil covering the surface of the earth represents the different between survival and extinction for most land-based life (Gliessman 1984). Soil quality is the phenomenon that has been developed to evaluate the factors effecting soil functionality. It is mainly concerned with sustainable use of soil resources in terms of enhanced agricultural productivity, environmental quality and human health. Basic soil quality indicators is expected to 
integrate the combined effects of the soil's physical, chemical and biological properties that together: (i) provide a medium for plant growth and biological activity, (ii) regulate and partition water flow and storage in the environment, and (iii) serve as an environmental buffer in the formation and destruction of environmentally hazardous compounds, (Dexter 2004 ; Larson and Pierce 1994).

Soil physical quality is manifest in various ways. Examples of poor physical quality are when soils exhibit one or more of the following symptoms: poor water infiltration, run-off of water from the surface, hard-setting, poor aeration, poor rootability, and poor workability. Good soil physical quality occurs when soils exhibit the opposite or the absence of the conditions listed above ( Dexter 2004). Chemical indicators include $\mathrm{pH}$, salinity, organic matter content, phosphorus availability, cation exchange capacity, nutrient cycling, and the presence of contaminants such as heavy metals, organic compounds, radioactive substances, etc. These indicators determine the presence of soil-plant-related organisms, nutrient availability, water for plants and other organisms, and mobility of contaminants (Anderson 2003).

Biological indicators represent different aspects of soil quality in different ecosystems. These indicators strive to monitor or measure three basic functions or parameters:

1. $\quad$ soil structure development; 2. nutrient storage; and 3. biological activity (Gregorich et al. 1994).

Many biological indicators of soil quality measure the processes or components of soil organic matter accumulation and mineralization. Biological indicators often recommended include: nitrogen mineralization, microbial biomass, microbial biomass to total carbon ratios, soil respiration, respiration to microbial biomass ratios, faunal populations and rates of litter decomposition. Respiration, used to measure microbial activity related to decomposition of organic matter in soil, and a commonly used index: the metabolic quotient (qCO2), defined as the respiration to microbial biomass ratio, which is associated to mineralization of organic substrate per unit of microbial biomass (Bastida et al. 2008).
Soil microbial activity leads to the liberation of nutrients available for plants but also to the mineralization and mobilization of pollutants and xenobiotics. Thus microbial activity is of crucial importance in biogeochemical cycling. Microbial activities are regulated by nutritional conditions, temperature and water availability. Other important factors affecting microbial activities are proton concentrations and oxygen supply. Microbial activity measurements include enzymatic assays that catalyze substrate-specific transformations and may be helpful to ascertain effects of soil management, land use and specific environmental conditions (Burns 1978).

Enzymes are biologically produced proteinic substances, having specific activation in which they combine with their substrates in such a stereoscopic position that they cause changes in the electronic configuration around certain susceptible bonds. Their significance in all spheres including soil is worth tested and reported. In plant nutrition, their role cannot be substituted by any other substance and their function is quite pragmatic in solubilizing and dissolving the much needed food in ionic forms for the very survival of the animal and plant kingdom. Enzymes are the key to understanding below-ground biochemistry and the role of soil in the global carbon cycle. These biological mediators of change are active both within living soil organisms and independently as extracellular proteins that are actively secreted into the soil by roots and fungi, or released as prokaryotic and eukaryotic cells that die and decompose. These enzymes can persist in the soil for weeks while maintaining a ghostly after life activity. Soil enzymes are a group of enzymes whose usual inhabitants are the soil and are continuously playing an important role in maintaining soil ecology, physical and chemical properties, fertility, and soil health. Soil enzymes play key biochemical functions in the overall process of organic matter decomposition in the soil system. They are important in catalyzing several important reactions necessary for the life processes of microorganisms in soils and the stabilization of soil structure, the decomposition of organic wastes, organic matter formation, and nutrient cycling, hence playing an important 
role in agriculture (Dick et al. 1994 ; Sinsabaugh et al. 1991).

The enzyme levels in soil systems vary in amounts primarily due to the fact that each soil type has different amounts of organic matter content, composition, and activity of its living organisms and intensity of biological processes. In practice, the biochemical reactions are brought about largely through the catalytic contribution of enzymes and variable substrates that serve as energy sources for microorganisms (Kiss et al. 1978). These enzymes may include amylase, arylsulphatases, b-glucosidase, cellulose, chitinase, dehydrogenase, phosphatase, protease, and urease. Soil dehydrogenases are the major representatives of the Oxidoreductase enzymes class. Among all enzymes in the soil environment, dehydrogenases are one of the most important, and are used as an indicator of overall soil microbial activity, because they occur intracellular in all living microbial cells (Gu et al. 2009).

The main purpose of the chapter is clarify description of the role of intracellular enzyme- dehydrogenase in the soil environment, and in the current chapter will concentrate on precise description of The most common laboratory procedure used for measured Dehydrogenase activity by two methods using the TTC and INT substrate.

\section{Soil Dehydrogenase Enzyme Activity}

The dehydrogenase enzyme activity is commonly used as an indicator of biological activity in soils (Burns 1978). This enzyme is considered to exist as an integral part of intact cells but does not accumulate extracellularly in the soil. Dehydrogenase enzyme is known to oxidize soil organic matter by transferring protons and electrons from substrates to acceptors. These processes are part of respiration pathways of soil microorganisms and are closely related to the type of soil and soil air-water conditions. Studies on the activity of dehydrogenase enzyme in the soil are very important as it may give indications of the potential of the soil to support biochemical processes which are essential for maintaining soil fertility. A study by (Brzezinska et al. 1998) suggested that soil water content and temperature influence dehydrogenase activity indirectly by affecting the soil redox status. The relationship between dehydrogenase activity and redox potential (Eh) as well as $\mathrm{Fe} 2+$ content may also be used to illustrate the reactions of soil microorganisms to the changes in soil environment.

Additionally, dehydrogenase enzyme is often used as a measure of any disruption caused by pesticides, trace elements, or management practices to the soil (Wilke 1991), as well as a direct measure of soil microbial activity. It can also indicate the type and significance of pollution in soils (Garcia and Hernandez 1997). It has been found that dehydrogenase enzyme is high in soils polluted with pulp and paper mill effluents but low in soils polluted with fly ash. Similarly, higher activities of dehydrogenases have been reported at low doses of pesticides and, lower activities of the enzyme at higher doses of pesticides. As most areas of the world are often polluted by different industrial bio-chemical products, better understanding of the role of this enzyme in environmental science will open greater possibilities of using it as a diagnostic tool for better ecosystem assessment and amelioration (Baruah et al. 1986 ; Leiros et al. 2000).

Dehydrogenases are generally present in every upper layer of soils. Soil microflora is responsible for the decomposition and conversion of organic substances, aggregation stability and the carbon, nitrogen, sulphur and phosphorus cycles. Dehydrogenases, as respiratory chain enzymes, play the major role in the energy production of organisms. They oxidize organic compounds by transferring two hydrogen atoms. Dehydrogenases play a significant role in the biological oxidation of soil organic matter $(\mathrm{OM})$ by transferring hydrogen from organic substrates to inorganic acceptors (Zhang et al. 2010). Many specific dehydrogenases transfer hydrogen to either nicotinamide adenine dinucleotide or nicotinamide adenine dinucleotide phosphate. Throughout mentioned co-enzymes hydrogen atoms are involved in the reductive processes of biosynthesis. Due to this fact, the overall DHA of a soil depends on the activities of various dehydrogenases, which are fundamental part of the enzyme system of all living microorganisms, like enzymes of the 
respiratory metabolism, the citrate cycle, and $\mathrm{N}$ metabolism (Subhani et al. 2001). Thus, DHA serves as an indicator of the microbiological redox-systems and could be considered a good and adequate measure of microbial oxidative activities in soil.

Brzezińska et al. (2001) found that active dehydrogenases can utilize both $\mathrm{O} 2$ and other compounds as terminal electron acceptors, although anaerobic microorganisms produce most dehydrogenases. Therefore, DHA reflects metabolic ability of the soil and its activity is considered to be proportional to the biomass of the microorganisms in soil. However, the relationships between an individual biochemical property of soil DHA and the total microbial activity is not always obvious, especially in the case of complex systems like soils, where the microorganisms and processes involved in the degradation of the organic compounds are highly diverse (Salazar et al. 2011).

\section{Different Method Used for Measurement of Dehydrogenase Activity}

Dehydrogenase activity can be considered to be a good measure of microbial oxidative activity in soils. It is usually determined by measuring the amount of an artificial electron acceptor reduced by microbial activity, such as a soluble tetrazolium salt with a red colored reduced form (a formazan) that can be determined colorimetrically following extraction with a suitable solvent. Concentration of soil dehydrogenases depends on conditions and intensity of biological conversion of organic compounds. Addition of suitable chemical (triphenyltetrazolium chloride) enhances bioavability of endogenous soil organic compounds to microflora. At the same time chloride is converged by hydrolytic reaction to formazan which can be extracted by organic solvents (methanol, acetone). Formazan concentration can be determined spectrophotometrically at $485 \mathrm{~nm}$. Addition of organic substrate, e.g. compost, induces maximum DHA. $\mathrm{H}$ can be transferred to soluble tetrazolium salts (e.g., TTC, INT) with the formation of red formazans, which can be determined calorimetrically after extraction with a solvent (Tabatabai 1982).

\section{Use of Tetrazolium Salts:}

Dehydrogenase assays based on the reduction of 2, 3, 5- triphenyltetrazolium chloride (TTC) to the creaming red-colored formazan (TPF), have been used to determine microbial activity in soil. The triphenyltetrazolium chloride (TTC) is a stable, water-soluble heterocyclic organic salt that can be easily reduced to form a highly colored insoluble product (red formazan), which can be quantified colorimetrically by visible light absorption (Ghaly and Mahmoud 2006).

Equations (1) and (2) describe the two step reaction of TTC (Lenhard et al. 1964):

a) Biological oxidation of organic compounds:

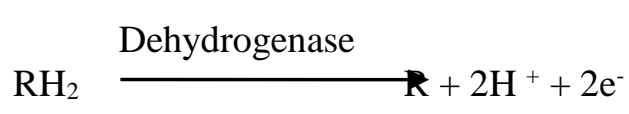

b) Chemical reduction of tetrazolium salts:

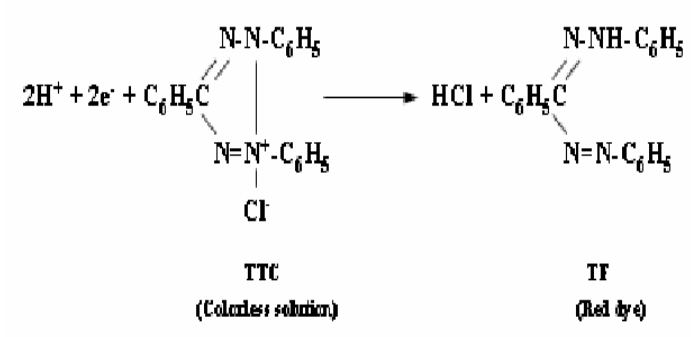

Lenhard (1956) appears to have been the first to use 2, 3, 5-triphenyltetrazolium chloride (TTC) in studies of microbial activity in soil. The method is based on the assumption that in the absence of $\mathrm{O} 2$ TIC acts quantitatively as the terminal $\mathrm{H}$ acceptor for dehydrogenase systems, with the formation of red triphenyltetrazoliumformazan (TPF):

$\mathrm{TTC}+2 \mathrm{H}++2 \mathrm{e}-=\mathrm{TPF}+\mathrm{HCI}$

When this test is applied to soil, the conditions are made anaerobic, and the aerobic dehydrogenases as well as the anaerobic dehydrogenases are assumed to use the TIC as $\mathrm{H}$ acceptor. If no substrate is added, the preferential stimulation of any group of organisms is avoided. If TTC does in fact act quantitatively as the terminal $\mathrm{H}$ acceptor for dehydrogenase systems, it replaces the respiratory enzyme chain which normally transfers the $\mathrm{H}$ and, in aerobic conditions, brings about combination of the $\mathrm{H}$ with 02 . When comparing $\mathrm{O} 2$ uptake and $\mathrm{CO} 2$ release, measurements have shown that 
only $4-5 \%$ of the $\mathrm{H}$ developed was recorded by the TTC reduction.

Various possible reasons have been proposed for these poor results (Von Mersi and Schinner 1991):

1. TTC inhibits the transformation by its own toxicity.

2. Not all the $\mathrm{H}$ is transferred to the TTC, when TTC functions as an $\mathrm{H}$ acceptor it is competitively inhibited, and reduction occurs only after other $\mathrm{H}$ acceptors are exhausted.

3. A cell can only take in a limited amount of TTC, so that the potential for TTC reduction is limited (2,3,5,-triphenyl formazan, TPF may cause the death of the cell).

Subsequent work produced similar results which led us to conclude that a measurement of TTC reduction is only a qualitative, not a quantitative, determination of biological activity, and suspect that the TTC method may not be very efficient.

TTC standard curve: Water-soluble tetrazolium salts are the preferred oxidants because they form water-insoluble colored formazans which can be measured spectrophotometrically. Soil was Prepared with $\mathrm{CaCO} 3$ and dispensed in three tubes as $6 \mathrm{~g}$ each. The total volume of fluids added to the soil was $3.5 \mathrm{ml}$; this included any fluids added during preincubation of the soil. Most substrate solution concentrations were $1 \%$ dextrose solutions. All of these were sterilized by autoclaving and $1 \mathrm{ml}$ was added to the soil at the time of TTC addition. However, the substrates were added as $0.5 \mathrm{ml}$ of a double-strength solution if there was danger of exceeding the $3.5-\mathrm{ml}$ fluid volume limit. TTC (Calbiochem, San Diego, Calif.) was prepared as a $3 \%$ aqueous solution and was sterilized by passage through a $0.30-$, um membrane filter (Millipore Corp., Bedford, Mass.). Each tube received $1 \mathrm{ml}$ of TTC, except for the soil blank, which received water instead. After addition, the water, substrate and TTC were simultaneously mixed through the soil with a sterile glass rod; then rubber stoppers were inserted and the tubes were incubated at $37^{\circ} \mathrm{C}$ at different incubation period of 6 hours, 12 hours and 24 hours. Upon completion of incubation, the tubes could be extracted immediately. Each soil sample was transferred with methanol to a funnel containing Whatman no. 5 filter paper (W. and R. Balston, Ltd.) placed on a 100-ml graduated cylinder. Additional portions of methanol were passed through the soil until $50 \mathrm{ml}$ of methanol, containing the formazan, had been collected in the graduated cylinder. If the filtrate passing from the funnel still had a red color, additional methanol was passed through the soil until all formazan had been extracted and corrections in calculations were made for the additional methanol. The red methanolic solutions of the formazan were read at $485 \mathrm{~nm}$ against the extract from the non-TTC soil blank by using a Spectronic 20 colorimeter (Bausch and Lomb, Rochester, N.Y.). The values obtained were compared against a formazan (Calbiochem) standard curve prepared with methanol and they are reported as milligrams of formazan per gram of soil (Kumar et al. 2013).

Although measuring the dehydrogenase activity using the TTC test depends on the biochemical reduction of the TTC, in addition, the medium $\mathrm{pH}$, incubation temperature, quantity of tetrazolium salt and incubation period are critical parameters that affect the accuracy of dehydrogenase activity measurements using tetrazolium salts (Mahmoud and Ghaly 2004).

\section{Use of P-Iodonitrotetrazolium Violet or INT salts:}

Various authors have used INT as a substrate to determine dehydrogenase activity. Benefield et al. (1977) and Grifiths (1989) used INT 2-(p-iodophenyl)-3- (pnitrophenyl)- 5-phenyltetrazolium chloride (p-iodonitrotetrazolium violet, or INT) as a substrate to determine dehydrogenase activity; which act as an artificial electron acceptor as a substrate to determined DHA in soil. Later, Trevors et al. (1982) used INT for the determination of dehydrogenase activity in soils, finding it to be more suitable than TTC for this purpose. The INT is reduced to iodonitrotetrazolium formazan (INTformazan) by soil enzymes and microorganisms and it was easily extracted without interference from phenolic compounds normally present in soil. The INT-formazan can be easily extracted with methanol and quantified spectrophotometrically. 
The production of formazan is affected by the conditions of reaction, for example, substrate concentration, temperature, duration, $\mathrm{pH}$ of any buffer added, degree of aeration and the addition of energy- yielding substrates (Trevors 1984).

Formazan is usually extracted from soil with methanol (Trevors et al. 1982) or ethanol (Roberge 1978) but other solvents have been used, for example $1: 1.5$ tetrachloretheylene : acetone (Benefield et al., 1977) and 1:9 acetone : trichloromethane (Benckiser et al. 1984). However, INT is less soluble in water, the INT reduction, like that of TTC, is strongly dependent on the soil reaction and gives values that are much too low compared to the TTC method when a soil with a high organic matter content is used. To alleviate the influence of soil reaction on dehydrogenase activity, optimal condition have been provided by using buffers with $\mathrm{pH}$ values between 7.0 and 8.0 (Von Mersi and Schinner 1991). The use of INT has been shown to give good reproducibility and differentiation of DHA in various soil types, where INT may actually be the superior substrate due to greater enzyme reduction, shorter incubation times and greater extractability of INTF from soils (Friedel et al. 1994; Rossel et al. 1997).

Grifiths (1989) and Von Mersi and Schinner (1991) have reported that, compard to TTC, INT is less toxic to microorganisms, INT affords a more accurate estimation of dehydrogenase activity than TTC, which they attributed to its higher electron affinity compared to TTC. As a consequence of this high electron affinity, INT competes more effectively with oxygen for free electrons and so it is not necessary to carry out the determinations under anaerobic conditions. Similar the results of Trevor (1984), comparison of TTC an INT, the INT method allows measurements in both aerobically and anaerobically incubated soils. They observed that the reduction from INT to INTF (iodonitrotetrazolium formazan) gives a more exact measurement of DHA in soil extracts, as $\mathrm{O} 2$ does not interfere with the INT reduction. More formazan is produced from the INT reduction than TTC, both with anaerobic and aerobic incubation.

Benefield et al. (1977) and Trevors (1984) compared the INT and TTC assay and concluded that the INT assay offered a better measure of DHA than the TTC assay. The INT method has the advantage of increased sensitivity over the TTC procedure or INT acceptor is more sensitive than TTC. INT is reduced more rapidly and easily than other tetrazolium compounds. This ensured by the strong electron affinity of INT in comparison to the other tetrazolium compounds.

\section{CONCLUSION}

The following are the significant findings emerging from the present study:

Soil dehydrogenase enzymes are one of the main components of soil enzymatic activities participating in and assuring the correct sequence of all the biochemical routes in soil biogeochemical cycles. It has also found that measurement of changes in soil enzyme activities may provide a useful index of changes in soil quality.

Dehydrogenase enzymatic activities is measured by two methods, namely use TTC and INT as substrate, however, various reported the poor results of DHA when TTC is used as substrate. The report sets out the finding of a study that both the INT and TTC assay can be applied to measure the DHA of anaerobic activated sludge in hydrogenproducing system. Furthermore, the INT assay has the advantage of increased sensitivity over the TTC procedure under the optimal conditions. INT assay, compared to TTC assay, requires less sludge and shorter time and turns out to be a more sensitive determination. Therefore, INT assay is more suitable to measure DHA in biohydrogen production system.

\section{REFERENCES}

Anderson $T$ (2003) Microbial Ecophysiological Indicators to Asses Soil Quality. Agriculture, Ecosystems and Environment 98:285-293

Bastida FZA, Hernández H, García C (2008) Past, Present and Future of Soil Quality Indices: A Biological Perspective. Geoderma 147:159-171

Baruah M, Mishra RR (1986) Effect of Herbicides Butachlor, 2,4-D and Oxyfluorfen on Enzyme Activities and CO2 Evolution in Submerged Paddy Field Soil. Plant and Soil. 96:287-291 
Benefield C, Howard PJA, Howard DM (1977) The Estimation of Dehydrogenase Activity in Soil. Soil Biology Biochemistry 9:67-70

Benckiser G, Santiago S, Neue HU, Watanabe I, Ottow JCG (1984) Effect of Fertilisation on Exudation, Dehydrogenase Activity, Iron-reducing Populations and $\mathrm{Fe}++$ Formation in The Rhizosphere of Rice (Oryza sativa L.) in Relation to Iron Toxicity. Plant and Soil 79:305-316

Burns RG (1978) Enzyme Activity in Soil: Some Theoretical and Practical. In:Burns RG (ed) Soil Enzymes. Academic Press, London, pp 295-340.

Brzezinska M, Stepniewska Z, Stepniewski W (1998) Soil Oxygen Status and Dehydrogenase Activity. Soil Biology and Biochemistry 30:1783-1790

Brzezińska M, Stępniewski W, Stępniewska Z, Przywara G, Wlodarczyk, T (2001) Effect of Oxygen Deficiency On Soil Dehydrogenase Activity In a Pot Experiment With Triticale cv. Jago Vegetation. International Agrophysics $15: 145-149$

Dexte, AR (2004) Soil Physical Quality. Part I. Theory, Effects of Soil Texture, Density, and Organic Matter, and Effects on Root Growth. Geoderma 120:201-214.

Dick RP, Sandor JA, Eash NS (1994) Soil Enzyme Activities After 1500 Years of Terrace Agriculture in The Colca Valley. Peru Agriculture Ecosystem Environment 50:123-131

Friedel JK, Molter K, Fischer WR (1994) Comparison and Improvement of Methods for Determining Soil Dehydrogenase Activity by Using Triphenyltetrazolium Chloride and Iodonitrotetrazolium Chloride. Biol Fertil Soils 18:291-296

Garcia C, Hernandez T (1997) Biological and Biochemical Indicators in Derelict
Soils Subject to Erosion. Soil Biology and Biochemistry 29 (2) :171-177

Ghaly AE, Mahmoud NS (2006) Optimum Conditions for Measuring Dehydrogenase Activity of Aspergillus niger using TTC. American Journal of Biochemistry and Biotechnology 2(4):186-194

Gliessman SR (1984) An Agroecological Approach to Sustainable Agriculture. In: Jackson W, Berry W, Colman B (ed) Meeting The Expectations of The Land. North Point Press, San Francisco, California pp 160-171

Gregorich EG, Carter MR, Angers DA, Monreal CM, Ellert BH (1994) Towards a Minimum Data Set to Assess Soil Organic Matter Quality in Agricultural Soils. Canadian Journal of Soil Science 74:367-385

Griffiths BS (1989) Improved Extraction of Iodonitrotetrazolium-Formazan From Soil With Dimethylformamide. Soil Biology and Biochemistry 21:179-180

Gu Y, Wag P, Kong C (2009) Urease, Invertase, Dehydrogenase and Polyphenoloxidase Activities In Paddy Soils Influenced By Allelophatic Rice Variety. European Journal of Soil Biology 45:436-441

Kiss S, Dragan-Bularda M, Radulescu D (1978) Soil polysaccharides: Activity and Agricultural Importance. In: Burns RG (ed) Soil Enzymes. Academic Press London, UK, pp 117-147

Kumar S, Chaudhuri S, Maiti SK (2013) Soil Dehydrogenase Enzyme Activity in Natural and Mine Soil - A Review. Maiti Middle-East Journal of Scientific Research 13 (7):898-906

Lenhard G (1956) Die Dehydrogenaseaktivität des Bodens als $\mathrm{Maß}$ für die Mikroorganismentätigkeit im Boden. Zeitschrift für Pflanzenernährung, Düngung, Bodenkunde 73:(1) 1-11

Lenhard G, Nourse LD, Schwartz HM (1964) The measurement of dehydrogenase 
activity of activated sludges. Advances in water pollution research. In: Baars JK (ed) Proceeding of the 2nd International Conference. Pergamon Press, Tokyo 2 pp 105-119

Larson WE, Pierce FJ (1994) The Dynamics of Soil Quality as A Measure of Sustainable Management. In: Doran JW, Coleman DC, Bezdicek DF, Stewart BA. Defining Soil Quality for A Sustainable Environment. Soil Science Society of America Special Publication no. 35, Madison, Winconsin pp 37-51

Leirós MC, Trasar-Cepeda, Seoane CS, GilSotres F (2000) Biochemical properties of acid soils under climax vegetation (Atlantic oakwood) in an area of the European temperate-humid zone (Galicia, NW Spain): general parameters. Soil Biology and Biochemistry 32:733-745

Mahmoud NS, Ghaly AE (2004) Influence of temperature and $\mathrm{pH}$ on the nonenzymatic reduction of triphenyltetrazolium chloride. Biotechnology Progress 20:346-35

McCarty GW, Siddaramappa R, Wright RJ, Codling EE, Gao G (1994) Evaluation of coal combustion by products as soil liming materials: their influence on soil $\mathrm{pH}$ and enzyme activities. Biology and Fertility of Soils 17(3):167-172

Roberge MR (1978) Methodology of soil enzyme measurement and extraction. In: Burns RG (ed) Soil Enzymes. Academic Press, London pp 341:370

Rossel D, Tarradellas J, Bitton G, Morel JL (1997) Use of Enzymes in Ecotoxicology: a Case for Dehydrogenase and Hydrolytic Enzymes. In: Tarradellas J, Bitton G, Rossel D. Soil Ecotoxicology. CRC Press pp 179-206

Von Mersi M, Schinner F (1991) An Improved an Accurate Method for Determining The Dehydrogenase Activity of Soils With Iodonitrotetrazolium Chloride. Biology and Fertility of Soils 11:216-220
Salazar S, Sanchez L, Alvarez J, Valverde A: Galindo P, Igual J, Peix, Santa-Regina AI Correlation Among Soil Enzyme Activities Under Different Forest System Management Practices. Ecological Engineering 37:1123-1131

Sinsabaugh RL, Antibus RK, Linkins AE (1991) An Enzymic Approach to The Analysis of Microbial Activity During Plant Litter Decomposition. Agric Ecosyst Environ 34:43-54

Subhani A, Changyong H, Zhengmiao Y, Min L, El-ghamry A (2001) Impact of Soil Environment and Agronomic Practices OnMicrobial/Dehydrogenase Enzyme Activity In Soil. A Review. Pakistan Journal of Biological Sciences 4:333-338

Tabatabai MA (1982) Soil Enzymes. In: Page AL, Miller RH, Keeney DR Methods of Soil Analysis. Part 2. Chemical and Microbiological Properties. Agronomy No. 9. ASA and SSSA, Madison, WI. pp 903-948

Trevors JT (1989) Effect of Substrate Concentration, Inorganic Nitrogen, $\mathrm{O}_{2}$ Concentration, Temperature and $\mathrm{pH}$ On Dehydrogenase Activity In Soil. Plant and Soil 77:285-293

Trevors JT, Mayfield CI, Inniss WE (1982) Measurement of Electron Transport System (ETS) Activity in Soil. Microbial Ecology 8:163-168

Wilke BM (1991) Effect of Single and Successive Additions of Cadmium, Nickel and Zinc on Carbondioxide Evolution and Dehydrogenase Activity in A Sandy Luvisol. Biology and Fertility of Soils 11:34-37

Zhang N, He X, Gao Y, Li, Y, Wang H, Ma D, Zhang R, Yang S (2010) Pedogenic Carbonate and Soil Dehydrogenase Activity In Response To Soil Organic Matter in Artemisia ordosica Community. Pedosphere 20:229-235 